\title{
Women are more religious than men; is this true?
}

\author{
Volume 2 Issue I - 2015 \\ Ivona Carapina \\ Department of Psychology, University of Mostar, Bosnia and \\ Herzegovina
}

\section{Introduction}

The terms religion and religiosity are intertwined with those that religion is more socially-cultural aspect and religiosity is more individual. ${ }^{1}$ An important question is how to measure religiosity because general religiosity cannot be operationalised and assessed, ${ }^{2}$ and more specific behavioural, emotional and cognitive aspects of religion and spirituality need to be identified. Most psychological research focuses on two measures of religiosity- belief and behavior. Some researchers have developed measures of religiosity and spirituality to suit their immediate research needs, and virtually all measures of religiosity have been developed in Christian contexts, and are unsuitable for use in other religious traditions. There are many questions that deal with religiosity and gender differences in religiosity is one of them. Interpretations of differences in religiosity between men and women can be reduced to several basic theories: socialization theory, theory of position in the social structure, gender schemas theory and essentialist theory. Socialization theory and theory of position in the social structure more concerned with the differences that are observed in the religious practice of women and men (reading Bible, pray), while gender schemas theory generally interpret differences in the concept of God and the various mystical endowment between men and women. ${ }^{3}$ Many researchers who took investigation in psychology of religiosity found that women are more religious than men and this has been the general conclusion in the social scientific and psychological literature. ${ }^{4}$ According to Smith et al., ${ }^{5}$ studies have shown that women more than men come to church, more follow religious instructions, more talk with clergy, more engage in daily prayer, more pray for their own benefit, more undertake religious education of the children and more use church for the acquisition of social support. In terms of intrinsic / extrinsic religious orientation, the results are not unambiguous. Either, there is no gender differences on any of the two subscales, or women achieve higher score than man on intrinsic scale ${ }^{6}$ of religiosity. Batson et al., ${ }^{7}$ in research who were predominantly on Christian samples, reports higher levels of attendance and Bible study among women than among men. Some authors suggested that gender differences in religiosity, such as higher levels of religious involment, prayer and religiosity generally among women comapred to men may be a reflection of greter opportunity among women for religious activity or differences in personality and socialization. ${ }^{8}$ Aim of study was to examine whether women are more religious than men, further differences in religiosity between man and women who live in small and big places were also examined.

\section{Materials and methods}

\section{Participants}

Gender differences in religiosity were examined among participants $(\mathrm{N}=296)$ between 16 and 50 age $(\mathrm{M}=25.40, \mathrm{sd}=6.99)$ who were selfdefined as Catholic (67.57\% women, $32.43 \%$ men). Participants were from Croatia and Bosnia and Herzegovina (Table 1).

\section{Instruments and Procedures}

Religiosity questionnaire measure three dimensions: dimension

\author{
Correspondence: Ivona Carapina, Department of Psychology, \\ Faculty of Humanities and Social Sciences, University of \\ Mostar, Mostar, Matice hrvatske bb, 88000 Mostar, Bosnia and \\ Herzegovina, Tel 0038763400 658, \\ Email carapina.ivona@gmail.com
}

Received: November 13, 2014 | Published: January 13, 2015

of spirituality, ritual / ritualistic dimensions of religiosity and dimension of faith influence on behaviour. The questionnaire consists of 24 items. Participants evaluate each statement on a scale of four levels $(0=$ false, $1=$ mostly false, $2=$ mostly true, $3=$ quite true $)$ depending on the extent to which the statement describes their usual behavior with higher scores reflecting greater religiosity. The scale range is from 0-72. Psychometric studies support good internal consistency, test retest reliability, and discriminant validity of this scale. Sociodemographic questionnaire which included questions about gender, age and place where participants live. All of participants completed both questionnaires on line in spring 2014.

\section{Results and discussion}

\section{Gender Differences}

Independent sample t-tests were conducted to examine gender differences in self-reported religiosity. As (Table 2) reveals, statistically significant differences were found for gender in ritual dimension of religiosity (Women Mean=17,32 Male Mean=14,29) and influence of religiosity on behaviour dimension (Women Mean=13,82 Male Mean $=10,59$ ). Women reached higher scores on both dimensions. Dimension of spirituality on this sample did not differ by gender.

\section{Place of living differences}

Independent sample t-tests were conducted to examine effect of place of living on religiosity. As (Table 3) reveals, no statistically significant differences were found between men who live in small and big places in any of dimension of religiosity.

\section{Place of living differences}

Independent sample t-tests were conducted to examine effect of place of living on religiosity. As (Table 4) reveals, statistically significant differences were found between women who live in small and big places in ritual dimension of religiosity (Women who live in small places Mean=14,82 Women who live in big places Mean=12,52). 
Table I Sample characteristics

\begin{tabular}{lll}
\hline $\mathrm{N}=296$ & \\
Age (years): $16-50$ & Mean $=25.40$ & Standard deviation $=6.99$ \\
Sex & Men & Women \\
$N(\%)$ & $95(32.43)$ & $201(67.57)$ \\
\hline
\end{tabular}

Table 2 Arithmetic mean, standard deviation of the dimensions of religiosity and differences between men and women

\begin{tabular}{|c|c|c|c|c|c|c|}
\hline \multirow[t]{2}{*}{ Dimension of Religiosity } & \multicolumn{2}{|c|}{ Women } & \multicolumn{2}{|l|}{ Men } & \multirow[b]{2}{*}{ t-value } & \multirow[b]{2}{*}{$\mathbf{p}$} \\
\hline & M & sd & $\mathbf{M}$ & SD & & \\
\hline Dimension of spirituality & 12.52 & 6.88 & $\mathrm{II} .8 \mathrm{I}$ & 6.47 & $\mathrm{I} .4$ & $P>0.05$ \\
\hline Ritual dimension of religiosity & 17.32 & 5.82 & 14.29 & 4.62 & 2.04 & $\mathrm{P}<0.05^{*}$ \\
\hline Influence of religiosity on behaviour dimension & 13.82 & 4.96 & 10.59 & 5.22 & 2.32 & $\mathrm{P}<0.05^{*}$ \\
\hline
\end{tabular}

Table 3 Arithmetic mean and standard deviation of the dimensions of religiosity and differences between men who live in small and big places

\begin{tabular}{|c|c|c|c|c|c|c|}
\hline \multirow[t]{2}{*}{ Dimension of Religiosity } & \multicolumn{2}{|c|}{ Men who live in small places } & \multicolumn{4}{|c|}{ Men who live in big places } \\
\hline & $\mathbf{M}$ & sd & $\mathbf{M}$ & SD & t-value & $\mathbf{p}$ \\
\hline Dimension of spirituality & 10.65 & 5.83 & 10.14 & 5.91 & 0.67 & $p>0.05$ \\
\hline Ritual dimension of religiosity & 13.69 & 6.74 & 12.49 & 7.47 & $1.40 \mathrm{I}$ & $P>0.05$ \\
\hline Influence of religiosity on behaviour dimension & 11.49 & 4.02 & 10.01 & 4.11 & $\mathrm{I} .28$ & $P>0.05$ \\
\hline
\end{tabular}

Table 4 Arithmetic mean and standard deviation of the dimensions of religiosity and differences between women who live in small and big places

\begin{tabular}{|c|c|c|c|c|c|c|}
\hline \multirow[t]{2}{*}{ Dimension of Religiosity } & \multicolumn{2}{|c|}{ Women who live in small places } & \multicolumn{4}{|c|}{ Women who live in big places } \\
\hline & $\mathbf{M}$ & sd & $\mathbf{M}$ & SD & t-value & $\mathbf{p}$ \\
\hline Dimension of spirituality & 10.33 & 3.62 & 10.01 & 3.33 & 0.138 & $P>0.05$ \\
\hline Ritual dimension of religiosity & 14.82 & 4.02 & 12.52 & 4.54 & 2.18 & $\mathrm{P}<0.05^{*}$ \\
\hline Influence of religiosity on behaviour dimension & $1 \mid .62$ & 5.84 & 10.59 & 5.92 & 0.78 & $P>0.05$ \\
\hline
\end{tabular}

\section{Conclusion}

Women reached higher scores on ritual dimension of religiosity and influence of religiosity on behaviour dimension and this findings are consistent with the literature previously reviewed and support findings that women are more religious than men. Differences in ritual dimension of religiosity are probably a result of traditional catholic upbringing where the mandatory rituals are part of the folk tradition, and partly because of socio-cultural changes which lead to greater openness in society towards religion and the church and such behaviors are socially desirable. Dimension of spirituality on this sample did not differ by gender. Also women who live in small places reached higher scores in ritual dimension than those who live in big places which suggests that influence of the church in smaller places is stronger. In smaller communities the social dynamics is intensive, so the pressure of the group for acceptance or rejection of certain behaviors pronounced awareness among the members can sample the acceptance of norms, including religious behavior than it is in urban areas. There is no differences between man in any dimension of religiosity regardless of place of living.

\section{Acknowledgments}

None.

\section{Conflicts of interest}

Author declares there are no conflicts of interest.

\section{Funding}

None.

\section{References}

1. Coric SS. Psihologija religioznosti. Naklada Slap. Jastrebarsko. 1997.

2. Glock CY, Stark R. Religion and society in tension. Chicago: Rand McNally and company, Chicago, USA. 1965. p.306.

3. Anic JR. Spolne razlike u religioznosti pod vidom obrazovanja. Bogoslovska smotra. 2008;78(4):873-903.

4. Loewenthal KM, MacLeod AK, Cinnirella M. Are women more religious than men? Gender differences in religious activity among different religious groups in the UK. Personality and Individual Differences. 2002;32(1):133-139.

5. Smith HL, Fabricatore A. Religiosity and Altruism Among African American Males. Journal of Black Studies. 1999;29(4):579-598.

6. Donahue MJ. Intrinsic and Extrinsic Religiousness Review and Meta-Analysis. Journal of Personality and Social Psychology. 1985;48(2):400-419.

7. Batson CD, Schoenrade PA, Ventis WL. Religion and the individual A social-psychological perspective. Oxford University Press, Oxford, UK. 1993. p.440.

8. Beit-Hallahmi B, Michael A. The Psychology of Religious Belief Behaviour and Experience. Routledge, New York, USA. 1997. p. 255. 